\title{
GUGATAN WARGA NEGARA SEBAGAI MEKANISME PEMENUHAN HAK ASASI MANUSIA DAN HAK KONSTITUSIONAL WARGA NEGARA
}

\author{
Abdul Fatah \\ efat77@yahoo.co.id \\ LBH Surabaya
}

\begin{abstract}
The purpose of the state law (rule of law) is to protect the rights and freedoms of human citizens to realize the general welfare, of the actions that an arbitrary ruler. It required strict regulation in order to protect citizens from becoming victims of arbitrariness state officials or authorities. A mechanism to protect the citizen right from abuse of power by government is through citizen lawsuit. However currently literature of citizen lawsuit is a weak in Indonesia, hence there should have been writing that discussion issues of citizen lawsuit from theory side.
\end{abstract}

Keywords: Rule of law, Human Rights, Government

\begin{abstract}
Abstrak
Tujuan dari negara hukum (rule of law) adalah melindungi hak-hak dan kebebasan asasi manusia warga negaranya untuk mewujudkan kesejahteraan umum, dari tindakan penguasa yang sewenang-wenang. Untuk itu diperlukan pengaturan yang tegas guna melindungi warga negara agar tidak menjadi korban dari kesewenangan petinggi negara atau penguasa. mekanisme untuk melindungi hak warga negara dari kesewenang-wenangan penguasa adalah melalui citizen lawsuit. Akan tetapi saat ini literatur mengaenai citizen lawsuit di Indonesia masih kurang, oleh karena itu perlu adanya tulisan yang membahas masalah citizen lawsuit dari sisi teori.
\end{abstract}

Kata kunci: Negara hukum, Hak Asasi Manusia, Pemerintah 


\section{Pendahuluan}

Konstitusi Indonesia (UUD 1945) menegaskan bahwa Negara Kesatuan Republik Indonesia adalah negara hukum (rule of law). ${ }^{1}$ Sebagaimana pemerintahan modern lainnya di dunia yang menganut negara hukum (rule oflaw), di Indonesia dikenal juga pemisahan kekuasaan (separation of power) dan perlindungan terhadap hak asasi manusia (protection of fundamental rigths). International Commission Of Jurist di New Delhi tahun 1959 juga mengemukakan bahwa salah satu karakteristik suatu negara yang menganut rule of law adalah adanya pengakuan dan perlindungan hak-hak asasi manusia dan the dignity of a man. ${ }^{2}$ Sedangkan ikrar Athena 1955 dari International Commission Of Jurist, mengemukakan bahwa sebagai prinsip utama negara hukum (rule of law) ialah :3 1)Negara harus tunduk kepada hukum; 2)Pemerintah harus menghormati hak-hak individu di bawah rule of law; 3)Hakim-hakim harus dibimbing oleh rule of law, melindungi dan menjalankan tanpa takut, tanpa memihak, dan menentang oleh setiap campur tangan pemerintah atau partai-partai terhadap kebebasannya sebagai hakim.

Negara hukum (rule of law) seperti Indonesia, harus memenuhi elemen-elemen penting dari sebuah negara hukum, yang merupakan ciri khas dan tidak boleh tidak ada (merupakan syarat mutlak), adalah :4 1)Asas pengakuan dan perlindungan hak-hak asasi manusia; 2) Asas legalitas; 3) Asas pembagian kekuasaan negara; 3)Asas peradilan yang bebas dan tidak memihak; 4) Asas kedaulatan rakyat; 5)Asas demokrasi, dan 6)Asas konstruksional.

Perubahan Kedua UUD 1945 juga memberikan ruang yang sangat luas bagi perlindungan hak asasi manusia (protection of fundamental rigths) di Indonesia. Hal ini dapat dilihat dengan adanya Bab XA tentang Hak Asasi Manusia di UUD 1945. Pengaturan hak asasi manusia di UUD 1945 ini melengkapi dan memperkuat regulasi yang sudah ada sebelumnya, yakni Undang-Undang Nomor 39 Tahun 1999 tentang Hak Asasi manusi (UU HAM). Akan tetapi, dengan diaturnya hak asasi manusia di dalam UUD 1945 tidak berbanding lurus dengan praktik pelanggaran hak asasi manusia di Indonesia. Tingkat praktik pelanggaran hak asasi manusia di Indonesia cukup tinggi. Pelanggaran hak asasi manusia di Indonesia menghadirkan negara (pemerintah) sebagai pelaku pelanggaran hak asasi manusia itu, baik pelanggaran secara langsung (by action) ataupun tidak langsung/pembiaran (by ommision).

Implikasi dengan diaturnya bab hak asasi manusia di dalam konstutusi (UUD 1945), negara dituntut untuk secara aktif memberikan jaminan dan perlindungan terhadap hak asasi manusia di Indonesia. Implikasi yang lain adalah hak asasi manusia menjadi hak konstitusional warga negara. Ketika bicara hak konsitusional warga negara, tidak bisa dilepaskan dari fungsi Mahkamah Konstitusi Republik Indonesia. Fungsi Mahkamah Konstitusi adalah melaksanakan constitutional review. Mahkamah Kontitusi dalam menjalankan fungsi contitutional review, memiliki dua tugas utama. Pertama, menjaga berfungsinya proses-proses demokrasi dalam

\footnotetext{
Lihat Pasal 1 Ayat (3) UUD 1945, Perubahan Kedua

A. Mukthie Fadjar, Tipe Negara Hukum, Malang: Bayumedia dan In-Trans, h. 33-34.

Ibid. 40-41

$4 \quad$ Ibid. 43
} 
hubungan saling mempengaruhi antara lembaga legislatif, eksekutif, dan yudikatif. Kedua, melindungi hak-hak atau kehidupan pribadi warga negara dari pelanggaran yang dilakukan oleh salah satu cabang kekuasaan negara. ${ }^{5}$

Dengan kata lain Mahkamah Konstitusi bertugas untuk menegakan prinsip-prinsip negara hukum dan memberi perlindungan maksimum terhadap demokrasi dan hak-hak dasar warga negara. ${ }^{6}$ Sehingga, pada dasarnya penegakan hukum terhadap praktik pelanggaran hak asasi manusia dengan pelaku pelanggarannya negara (pemerintah) tidak hanya domain Pengadilan Hak Asasi Manusia (Pengadilan HAM) dan Peradilan Umum sebagaimana yang telah diatur dalam UU HAM dan Undang-Undang Nomor 26 Tahun 2000 tentang Pengadilan Hak Asasi Manusia (Pengadilan HAM), akan tetapi dapat disengketakan di Mahkamah Konstitusi.

Akan tetapi, Mahkamah Konstitusi sebagai lembaga pengawal konstitusi (the guardian of the constitution) dan penafsir final konstitusi (the final interpeter of the constitution) mempunyai keterbatasan dalam menjalankan fungsi dan tugasnya. Hal itu disebabkan, Mahkamah Konstitusi sebagaimana Pasal 24C Ayat (1) dan (2) UUD 1945 mempunyai empat kewenangan dan satu kewajiban yaitu mengadili pada tingkat pertama dan terakhir yang putusannya bersifat final, menguji undang-undang terhadap Undang-Undang Dasar, memutus sengketa kewenangan lembaga negara yang kewenangannya diberikan oleh Undang-Undang Dasar, memutus pembubaran partai politik dan memutus perselisihan tentang hasil pemilihan umum. Dan kewajiban Mahkamah Konstitusi adalah memberikan putusan atas pendapat Dewan Perwakilan Rakyat mengenai dugaan pelanggaran oleh Presiden dan/atau Wakil Presiden menurut UndangUndang Dasar. Dengan empat wewenang dan satu kewajiban Mahkamah Konstitusi tidak dapat menjalankan fungsinya sebagai contitutional review. Sudah semestinya Mahkamah Konstitusi dalam menjalankan fungsinya sebagai contitutional review, diberikan kewenangan yang lebih luas sebagaimana di negara-negara modern lainnya yang ada Mahkamah Konstitusinya. Kewenangan tersebut misalnya memeriksa, mengadili dan memutus perkara Constitutional Complaint, Constitutional Question, dan Gugatan Warga Negara terhadap tanggung jawab Penyelenggara Negara atas kelalaian dalam memenuhi hak-hak konstitusional dan hak asasi manusia warga negara (Citizen Lawsuit).

Salah satu hal yang menarik dari ketiga tawaran di atas adalah Citizen Lawsuit. Citizen Lawsuit di Indonesia sudah ada beberapa kasus/perkara, akan tetapi melalui gugatan di peradilan umum, yakni di bawah kendali pemegang kekuasaan kehakiman yang lain Mahkamah Agung. Salah satu kelemahan Citizen Lawsuit di Indonesia adalah tidak adanya regulasi yang mengatur. Oleh sebab itu, karena bicara Citizen Lawsuit adalah bicara tanggung jawab Penyelenggara Negara atas kelalaian dalam memenuhi hak-hak warga Negara. Hal ini menjadi domain Mahkamah Konsitusi. Sehingga Citizen Lawsuit menjadi tawaran menarik sebagai makenisme

\footnotetext{
5 Moh. Mahfud MD, dkk, 2010, Constitutional Question : Alternatif Baru Pencarian Keadilan Konstitusional, Malang: UB Press, h. 28-29

6 Ibid, h. 29
} 
pemenuhan hak asasi manusia dan hak konstitusional warga negara melalui sengkata di Mahkamah Konstitusi.

\section{Pembahasan}

Citizen Lawsuit atau Gugatan Warga Negara terhadap penyelenggara Negara sebenarnya tidak dikenal dalam sistem hukum Civil Law sebagaimana yang diterapkan di Indonesia. Citizen Lawsuit sendiri lahir di negara-negara yang menganut sistem hukum Common Law, misalnya di Amerika Serikat, India, dan Australia. Dan dalam sejarahnya Citizen Lawsuit pertama kali diajukan terhadap permasalahan lingkungan hidup. Namun pada perkembangannya, Citizen Lawsuit tidak lagi hanya diajukan dalam perkara lingkungan hidup, tetapi pada semua bidang dimana negara dianggap melakukan kelalaian dalam memenuhi hak-hak warga negaranya. Pada hakekatnya gugatan warga negara (Citizen Lawsuit) adalah akses orang perorangan warga negara untuk keseluruhan warga negara atau kepentingan publik termasuk kepentingan lingkungan mengajukan gugatan di pengadilan guna menuntut agar pemerintah atau negara melakukan penegakan hukum yang diwajibkan kepadanya atau untuk memulihkan kerugian publik yang terjadi. ${ }^{7}$

Michael D. Axline, menegaskan bahwa Citizen lawsuit memberikan kekuatan kepada setiap warga negara untuk menggugat pihak tertentu (privat) yang melanggar undang-undang, dan juga memiliki kekuatan untuk menggugat negara dan lembaga-lembaga (federal) yang melakukan pelanggaran undang-undang, atau yang gagal dalam memenuhi kewajibannya dalam melaksanakan (implementasi) undang-undang. ${ }^{8}$ Sedangkan menurut Gokkel, adalah gugatan yang dapat diajukan oleh setiap warga negara, tanpa pandang bulu, dengan pengaturan oleh negara. ${ }^{9}$ Citizen lawsuit dikenal juga dengan Actio Popularis.

Beberapa Kasus Citizen Lawsuit yang cukup dikenal adalah sebagai berikut:

\section{Di Amerika Serikat}

Gugatan seorang Warga Negara Amerika atas kelalaian Pemerintah dalam melakukan pelestarian terhadap Spesies kelelawar langka di Amerika. Gugatan tersebut dikabulkan dan hasilnya adalah pemerintah Amerika mengeluarkan Act tentang Konservasi kelelawar langka tersebut.

\section{Di India}

Gugatan seorang Warga Negara India atas kelalaian Pemerintah India dalam melestarikan sungai gangga yang merupakan sungai suci bagi umat hindu. Hasilnya adalah Larangan

\footnotetext{
7 Dhabi K. Gumayra (Kontributor), Panduan Bantuan Hukum di Indonesia, Jakarta: Aussaid, YLBHI, PSHK dan IALDF, 2006, h. 382.

8 Hermawanto (Kontributor), Panduan Bantuan Hukum di Indonesia, Jakarta: Aussaid, YLBHI, PSHK dan IALDF, 2008, h. 500.

$9 \quad$ Ibid, h. 501
} 
pemerintah India kepada pabrik-pabrik di sekitar sungai Gangga melakukan pencemaran terhadap sungai. Citizen Lawsuit pada dasarnya adalah mekanisme bagi Warga Negara untuk menggugat tanggung jawab Penyelenggara Negara atas kelalaian dalam memenuhi hak-hak warga Negara. Kelalaian tersebut didalilkan sebagai Perbuatan Melawan Hukum, sehingga Citizen Lawsuit diajukan pada lingkup peradilan umum dalam hal ini perkara Perdata. Oleh karena itu Atas kelalaiannya, dalam petitum gugatan, Negara dihukum untuk mengeluarkan suatu kebijakan yang bersifat mengatur umum (regeling) agar kelalaian tersebut tidak terjadi lagi di kemudian hari.

Karakteristik Citizen Lawsuit, sebagai berikut : 1)Tergugat dalam Citizen Lawsuit adalah penyelenggara negara, mulai dari presiden dan wakil presiden sebagai pimpinan teratas, menteri dan terus sampai kepada pejabat negara di bidang yang dianggap telah melakukan kelalaian dalam memenuhi hak warga negaranya. 2)Perbuatan melawan hukum yang didalilkan dalam gugatan adalah kelalaian penyelenggara negara dalam pemenuhan hak-hak warga negara. Dalam hal ini harus diuraikan bentuk kelalaian apa yang telah dilakukan oleh negara dan hak warga negara apa yang gagal dipenuhi oleh negara. 3)Penggugat adalah warga negara, yang bertindak mengatasnamakan warga negara. penggugat dalam hal ini cukup membuktikan bahwa dirinya adalah warga negara Indonesia. 4)Citizen Lawsuit tidak memerlukan adanya suatu notifikasi Option Out setelah gugatan didaftarkan sebagaimana diatur dalam PERMA tentang Class Action. Dalam praktiknya di Indonesia yang didasarkan pada pengaturan di beberapa negara Common Law, Citizen Lawsuit cukup hanya dengan memberikan notifikasi berupa somasi kepada penyelenggara Negara. 5)Petitum dalam gugatan tidak boleh meminta adanya ganti rugi materiel, karena kelompok warga negara yang menggugat bukan kelompok yang dirugikan secara materiel dan memiliki kesamaan kerugian dan kesamaan fakta hukum sebagaimana gugatan Class Action. 6)Petitum Citizen Lawsuit harus berisi permohonan agar negara mengeluarkan suatu kebijakan yang mengatur umum (Regeling) agar perbuatan melawan hukum berupa kelalaian dalam pemenuhan hak warga negara tersebut di masa yang akan datang tidak terjadi lagi.

Kareketeristik yang lain, adalah sebagai berikut $:{ }^{10}$ a) Citizen Lawsuit merupakan akses orang per orang atau warga negara untuk mengajukan permohonan di pengadilan untuk dan atas nama kepentingan keseluruh warga negara atau kepentingan publik; b) Citizen Lawsuit bertujuan untuk melindungi warganegara dari kemungkinan terjadinya kerugian sebagai akibat dari tindakan atau pembiaran negara atau otoritas negara; c) Citizen Lawsuit memberikan kekuatan kepada warga negara untuk menggugat negara dan institusi pemerintah yang melakukan pelanggaran undang-undang atau yang melakukan kegagalan dalam memenuhi kewajibannya dalam memenuhi kewajibannya dalam pelaksanaan (implementasi) undangundang; d) Orang perorangan warga negara yang menjadi pemohon dalam Gugatan Citizen Lawsuit tidak perlu membuktikan adanya kerugian langsung yang bersifat riil atau tangible;

10 Hermawanto, Op. Cit, h. 501 
Secara umum peradilan cenderung kurang menerima tuntutan ganti rugi jika diajukan dalam bentuk permohonan Citizen Lawsuit.

Tabel 1. Kasus-Kasus Citizen Lawsuit di Indonesia

\begin{tabular}{lll}
\hline No. & Kasus & Keterangan \\
\hline 1. & Citizen Lawsuit atas nama Munir Cs & Dikabulkan Majelis Hakim Jakarta Pusat \\
& atas Penelantaran Negara terhadap TKI & dengan Ketua Majelis Andi Samsan \\
& Migran yang dideportasi di Nunukan. & Nganro. Hasilnya adalah UU Nomor 39 \\
& & Tahun 2004 tentang Penempatan dan \\
& perlindungan Tenaga Kerja Indonesia. Ini \\
& merupakan Citizen Lawsuit pertama yang \\
& muncul di Indonesia \\
\hline Citizen Lawsuit atas kenaikan Bahan & Tidak diterima Majelis Hakim PN Jakarta \\
& Bakar Minyak oleh LBH APIK & Pusat \\
\hline Citizen Lawsuit atas Operasi Yustisi & Tidak diterima Majelis Hakim PN Jakarta \\
& oleh LBH Jakarta & Pusat \\
\hline Citizen Lawsuit atas penyelenggaraan & Dikabulkan untuk sebagian. \\
& Ujian Nasional oleh LBH Jakarta
\end{tabular}

Dalam pelaksanaan Citizen Lawsuit, ada beberapa persyaratan yang harus dipenuhi, yaitu : ${ }^{11} 1$ ) Adanya Standing, Penggugat harus memiliki standing untuk melaksanakan gugatan ini, berarti seseorang ataupun sekelompok orang sekelompok orang dikatakan dapat memiliki standing apabila ada kepentingan hukum, yang biasanya dikaitkan dengan kepentingan kepemilikan (propietary interest) atau kerugian yang langsung dialami oleh penggugat (Injury in fact). Jika pemohon terbukti tidak memiliki standing maka tergugat dapat meminta pembatalan gugatan. Namun dalam Citizen Lawsuit, standing yang utama adalah warga negara Indonesia. 2) Adanya pemberitahuan (notifikasi) Peraturan mengenai Citizen Lawsuit di Amerika Serikat mensyaratkan bahwa orang perorangan warga negara harus melakukan pemberitahuan terlebih dahulu tentang maksud dan tujuan pengajuan gugatan sebelum didaftarkan. Pemberitahuan dimaksud harus merinci pelanggaran dan tuntutan yang spesifik untuk kemudian menjadi dasar pengajuan gugatan. Rincian pelanggaran dan tuntutan tersebut diberikan kepada pelanggar dan instansi yang bertanggung jawab menerapkan peraturan perundang-undangan yang memberikan hak Citizen Lawsuit.

Pemberitahuan dalam Citizen Lawsuit bertujuan untuk: a) Memberikan dorongan/ intensif bagi pelanggar agar melakukan penataan; b) Memberikan kesempatan secara fair kepada tergugat untuk mengajukan bantahan dalam kesempatan paling awal dari proses penanganan perkara; c) Kegagalan dalam menyediakan pemberitahuan yang memenuhi syarat dapat dipergunakan sebagai alasan untuk menolak gugatan; d) Memberikan pendidikan

\footnotetext{
11 Ibid, h. 502
} 
kepada penggugat untuk mengajukan gugatan dengan dilengkapi bukti dan fakta yang akurat. Berkaitan dengan waktu, bentuk dan isi pemberitahuan dimana dalam sistem yang berlaku di Amerika Serikat, pemberitahuan (notice) harus dikirimkan selambat-lambatnya 60 hari sebelum tuntutan hukum diajukan. Batas waktu pemberitahuan ini menjadi penting, karena tidak terpenuhinya batasan waktu tersebut dapat dijadikan dasar alasan untuk mengajukan mosi penolakan Citizen Lawsuit. Pada prinsipnya, pemberitahuan Citizen Lawsuit harus dibuat dalam bentuk tertulis dan dikirimkan, baik kepada pelanggar yang dituduh maupun kepada instansi yang bertanggung jawab untuk mengimplementasikan undang-undang yang dilanggar, serta kepada lembaga negara yang bertanggung jawab dalam penegakan hukum. Pemberitahuan dalam Citizen Lawsuit harus memuat : a) Informasi tentang pelanggaran yang dituduhkan dan lembaga yang relevan dengan pelanggaran yang berdasarkan hal itu pemohon berniat untuk menggugat kepada tergugat; b) Jenis pelanggaran/objek gugatan.

Secara normatif tidak ada regulasi di Indonesia yang mengatur Citizen Lawsuit. Akan tetapi dengan banyaknya perkara Citizen Lawsuit yang pernah ada, ini menunjukan ada legitimasi dari lembaga peradilan, dalam hal ini Peradilan Umum di bawah naungan Mahkamah Agung, ditambah lagi ada perkara yang dikabulkan dan ini menjadi yurisprudensi di Indonesia.

Tabel 2. Perbandingan Karakteristik Gugatan Citizen Lawsuit dengan Gugatan yang lain ${ }^{12}$

\begin{tabular}{|c|c|c|c|c|}
\hline & $\begin{array}{l}\text { Gugatan } \\
\text { Perdata Biasa }\end{array}$ & Class Action & Legal Standing & Citizen Law Suit \\
\hline Filosofi & Individualistik & $\begin{array}{l}\text { Ketidakpercayaan } \\
\text { pada individualistik }\end{array}$ & $\begin{array}{l}\text { NGO/LSM } \\
\text { sebagai wali } \\
\text { (Guardian) }\end{array}$ & $\begin{array}{l}\text { Individu mampu mewakili } \\
\text { kepentingan publik }\end{array}$ \\
\hline Istilah & Gugatan Perdata & $\begin{array}{l}\text { Gugatan Perwakilan } \\
\text { Kelompok }\end{array}$ & $\begin{array}{l}\text { Gugatan NGO/ } \\
\text { NGO Standing }\end{array}$ & Gugatan Warga Negara \\
\hline $\begin{array}{l}\text { Hubungan } \\
\text { Kepentingan }\end{array}$ & $\begin{array}{l}\text { Kepentingan } \\
\text { Langsung (riil \& } \\
\text { tangible) }\end{array}$ & $\begin{array}{l}\text { Kepentingan } \\
\text { Langsung (riil \& } \\
\text { tangible) }\end{array}$ & $\begin{array}{l}\text { Tidak memiliki } \\
\text { Kepentingan } \\
\text { Langsung (riil } \\
\text { \& tangible) }\end{array}$ & $\begin{array}{l}\text { Tidak memiliki Kepentingan } \\
\text { Langsung (riil \& tangible) }\end{array}$ \\
\hline Tuntutan & $\begin{array}{l}\text { Ganti rugi } \\
\text { materiil dan } \\
\text { tindak tertentu }\end{array}$ & $\begin{array}{l}\text { Ganti rugi materiil } \\
\text { dan tindak tertentu }\end{array}$ & $\begin{array}{l}\text { Tindakan } \\
\text { tertentu \& } \\
\text { out of pocket } \\
\text { expenses }\end{array}$ & $\begin{array}{l}\text { Tindakan tertentu, } \\
\text { pelaksanaan kewajiban } \\
\text { hukum }\end{array}$ \\
\hline Subjek & $\begin{array}{l}\text { Orang yang } \\
\text { dirugikan secara } \\
\text { langsung }\end{array}$ & $\begin{array}{l}\text { Class Representative, } \\
\text { Class Members }\end{array}$ & $\begin{array}{l}\text { Organisasi } \\
\text { yang memenuhi } \\
\text { syarat }\end{array}$ & $\begin{array}{l}\text { Orang perorangan warga } \\
\text { negara }\end{array}$ \\
\hline Notifikasi & Tidak diperlukan & $\begin{array}{l}\text { Notifikasi dari Class } \\
\text { Representative ke } \\
\text { Class Member }\end{array}$ & $\begin{array}{l}\text { Tidak } \\
\text { diperlukan }\end{array}$ & $\begin{array}{l}\text { Notifikasi dari Penggugat ke } \\
\text { Tergugat }\end{array}$ \\
\hline
\end{tabular}


PraktikCitizen Lawsuit di Indonesia, selama ini di ajukan di Peradilan Umum (dibawah naungan Mahkamah Agung). Ada dua alasan pokok, kenapa Citizen Lawsuit diajukan di Peradilan Umum. Pertama, kekuasaan kehakiman ketika pertama kali Citizen Lawsuit muncul di Indonesia, hanya ada di Mahkamah Agung. Sehingga Citizen Lawsuit sebagaimana gugatan lainnya di ajukan di Peradilan Umum (Pengadilan Negeri). Kedua, belum adanya regulasi yang mengatur Citizen Lawsuit di Indonesia. Sehingga dengan berpatokan pada asas "hakim tidak boleh menolak suatu perkara dengan dalil tidak ada dasar hukumnya" maka alasan itulah yang kemudian melatarbelakangi Citizen Lawsuit di Indonesia diajukan di Peradilan Umum.

Secara subtansi, diajukannya Citizen Lawsuit ke Peradilan Umum adalah kurang tepat. Pada dasarnya Citizen Lawsuit merupakan upaya hukum dari warga negara untuk mempermasalahkan tanggung jawab penyelenggara negara atas kelalaian dalam memenuhi hak-hak warga negara. Hak-hak warga negara di negara berdasarkan hukum (rule of law), seperti Indonesia sudah diatur di dalam UUD 1945. Bahkan hak asasi manusia pun juga diatur di dalam UUD 1945. Sehingga hak-hak warga negara tersebut lazimnya disebut dengan "Hak

\section{Konstitusional Warga Negara".}

Berbicara hak konstitusional warga negara, akan bersinggungan dengan lembaga yang berfungsi sebagai contitutional review, yaitu Mahkamah Konsitusi. Sebagai lembaga yang dibentuk untuk melindungi hak-hak atau kehidupan pribadi warga negara dari pelanggaran yang dilakukan oleh salah satu cabang kekuasaan negara, Mahkamah Konsitusi berwenang untuk memeriksa sengketa antara warga negara dengan penyelenggara negara dengan alasan penyelenggara negara telah lalai dalam pemenuhan hak-hak warga negara. Dengan kata lain, Mahkamah Konstitusi berwenang untuk mengadili perkara Citizen Lawsuit (gugatan warga negara). Indonesia sebagai negara demokratis dan berdasarkan hukum sebagaimana Pasal 1 Ayat (2) dan (3) UUD 1945, yang sudah memiliki Mahkamah Konstitusi dengan fungsi contitutional review. Menerapkan Gugatan Citizen Lawsuit dengan kewenangan ada di Mahkamah Konstitusi bukanlah hal yang mustahil. Dan pemerintah harus berani membuat regulasi tentang Citizen Lawsuit di Indonesia dibawah kewenangan Mahkamah Konstitusi.

Sebagaimana diketahui bersama bahwa di Indonesia belum ada peraturan berundangundangan yang secara khusus mengatur Gugatan Citizen Lawsuit. Selama ini praktik Citizen Lawsuit hanya didasarkan pada Putusan Nomor : 28/Pdt.G/2003/PN. JKT.PST yang diputus pada tanggal 8 Desember 2003 antara J. Sandyawan Sumarji dan kawan-kawan (sebanyak 53 orang) sebagai Pemohon/Pengugat melawan Negara Republik Indonesia c.q Kepala Negara, Presiden Republik Indonesia Megawati Soekarno Putri sebagai Tergugat. Kasus ini biasa disebut dengan sebutan “Citizen Lawsuit Nunukan”.

Gugatan ini dikabulkan oleh Majelis Hakim, Pengadilan Negeri Jakarta Pusat dengan isi Putusan sebagai berikut : a) UU Nomor 14 Tahun 1970 tentang Ketentuan Pokok Kekuasaan Kehakiman jo. UU Nomor 35 Tahun 1999, Pasal 14 Ayat (1) : Pengadilan tidak boleh menolak untuk memeriksa dan mengadili sesuatu perkara yang diajukan dengan dalil bahwa tidak atau 
kurang jelas, melainkan wajib untuk memeriksa dan mengadilinya; b) Pasal 27 UU Nomor 14 Tahun 1970 tentang Ketentuan Pokok Kekuasaan Kehakiman: Hakim sebagai penegak hukum dan keadilan wajib menggali, mengikuti dan memahami nilai-nilai yang hidup di dalam masyarakat; c) Permohonan yang diajukan adalah citizen lawsuit yang biasa dikenal dengan sebutan actio popularis, yakni prosedur pengajuan gugatan yang melibatkan kepentingan umum (public interest) secara perwakilan; d) Setiap warga negara tanpa kecuali mempunyai hak untuk membela kepentingan umum. Dengan demikian, setiap warga negara atas nama kepentingan umum (on behalf of the public interest) dapat menggugat negara atau pemerintah atau siapapun yang melakukan perbuatan melawan hukum, yang nyata-nyata merugikan kepentingan publik dan kesejahteraan luas (pro bono publico). Hal ini sejalan dengan prinsip HAM tentang akses untuk mendapatkan keadilan apabila negara diam atau tidak melakukan tindakan apapun untuk kepentingan warga negaranya (acces to justice).

Berdasarkan putusan di atas menunjukan ada kekosongan hukum terkait dengan Citizen Lawsuit di Indonesia. Dan hakim dalam memutus perkara berlindungan di Undang-Undang Kekuasan Kehakiman "hakim tidak boleh menolak perkara”. Oleh sebab itu, perlu dibentuk/ disusun regulasi yang mengatur Citizen Lawsuit di Indonesia. Dalam Citizen Lawsuit yang menjadi poin utamanya adalah hak warga negara yang dilalaikan oleh penyelenggara negara. Dari beberapa perkara Citizen Lawsuit yang pernah ada, kebanyakan mempermasalahkan terlanggarnya hak asasi manusia. Masalah utama dalam hal Citizen Lawsuit ini adalah tidak adanya payung hukum dan kewenangan untuk mengadilinya ada di mana. Apakah di Mahkamah Agung ataukah di Mahkamah Konsitusi? Untuk saat ini, perkara Citizen Lawsuit masih dijalankan/ diterima Peradilan Umum dengan ratio legis sebagimana Putusan Nomor : 28/Pdt.G/2003/ PN. JKT.PST yang diputus pada tanggal 8 Desember 2003, yakni hakim tidak boleh menolak perkara. Padahal saat ini, sebagaimana Pasal 24 Ayat (2) UUD 1945 "Kekuasaan Kehakiman dilakukan oleh sebuah Mahkamah Agung dan badan peradilan yang berada di bawahnya dalam lingkungan peradilan umum, lingkungan peradilan agama, lingkungan peradilan militer, lingkungan peradilan tata usaha negara dan oleh sebuah Mahkamah Konstitusi”. ${ }^{13}$

Intinya adalah kekuasaan kehakiman untuk saat ini tidak hanya ada di Mahkamah Agung, akan tetapi ada juga pada Mahkamah Konstitusi. Maka ada potensi perkara Citizen Lawsuit dapat didaftarkan/disengketakan di Mahkamah Konstitusi. Karena hakim konstitusi tidak boleh menolak perkara Citizen Lawsuit dengan dalil tidak ada sumber hukumnya. Pasal 24C UUD 1945 memberikan limitasi terhadap kewenangan Mahkamah Konstitusi. Akan tetapi sebagai negara yang demokratis dan berdasarkan hukum sebagaimana Pasal 1 Ayat (2) dan (3) UUD 1945. Dua konsekwensi terpenting dari penegasan ini, sesuai dengan prinsip constitutionalism dan penghormatan, perlindungan, serta pemenuhan hak-hak asasi manusia yang menjadi penanda penting negara demokratis dan negara hukum adalah $:{ }^{14}$ Pertama, konstitusi (in casu UUD

\footnotetext{
13 Lihat Undang-Undang Nomor 48 Tahun 2009 tentang Kekuasaan Kehakiman

14 Moh. Mahfud MD, dkk, Op. Cit, h. 45
} 
1945), sebagai hukum tertinggi, harus benar terjelma dan dilaksanakan dalam praktik sehingga seluruh praktik penyelenggaraan kehidupan bernegara tidak boleh bertentangan dengan UUD 1945; Kedua, tatkala hak-hak asasi manusia itu telah dimasukan ke dalam konstitusi diakui sebagai hak konstitusional warga negara, yang berarti ia telah menjadi bagian dari ketentuan konstitusi, maka seluruh cabang kekuasaan negara terikat untuk menaatinya.

Citizen Lawsuit adalah gugatan yang diajukan dengan harapan dipenuhinya hak-hak asasi manusia (karena sudah masuk di UUD 1945, disebut sebagai Hak Konstitusional Warga Negara). Sedangkan Mahkamah Konstitusi dibentuk sebagai pengawal konstitusi (UUD 1945), maka Mahkamah Konstitusi dituntut untuk menjamin bahwa UUD 1945 benar-benar terjelma dan ditaati dalam praktik, termasuk didalamnya menjamin bahwa hak-hak konstitusional warga negara benar-benar dihormati, dilindungi, dan dipenuhi dalam praktik penyelenggaran negara. ${ }^{15}$ Disitulah posisi Mahkamah Konstitusi untuk dapat menyidangkan perkara-perkara Citizen Lawsuit dengan menghadirkan setiap warga negara menjadi penggugat atau pemohon dan pemerintah sebagai tergugat/termohon, dengan permohonan pemenuhan hak-hak konstitusional warga negara (yang di dalamnya ada hak-hak asasi manusia). Misalnya hak atas pendidikan, kesehatan, untuk beragama dan berkayakinan. Dengan posisi Mahkamah Konstitusi secara aktif menyidangkan perkara Citizen Lawsuit, fungsi Mahkamah Konstitusi sebagai lembaga pengawal konstitusi akan lebih jauh dapat dirasakan oleh warga negara.

Mahkamah Konstitusi, tidak hanya terjebak dalam satu kewenangan yaitu menguji undang-undang terhadap UUD 1945. Salah satu alasan undang-undang diuji dengan UUD 1945 yaitu adanya kerugian konstitusional warga negara yang dikandung undang-undang bersangkutan. Hal ini menunjukan pembentuk undang-undang yang berpandangan bahwa pelanggaran hak-hak konstitusional warga negara itu disebabkan norma undang-undang saja. Misalnya undang-undang APBN yang tidak memberikan alokasai anggaran 20 persen (\%) untuk pendidikan, ini bertentangan dengan Pasal 31 Ayat (4) UUD 1945 "Negara memprioritaskan anggaran pendidikan sekurang-kurangnya dua puluh persen dari anggaran pendapatan dan belanja negara serta dari anggaran pendapatan dan belanja daerah untuk memenuhi kebutuhan penyelenggaraan pendidikan nasional".

Padahal pelanggaran hak konstitusional warga negara, salah satunya hak asasi manusia ada tidak hanya persoalan norma dalam undang-undang. Akan tetapi, yang lebih berbahaya adalah pelanggaran secara langsung yang dilakukan oleh pemerintah baik itu by action ataupun by ommision. Di situlah posisi Mahkamah Konstitusi untuk menyidangkan gugatan warga negara terhadap negara/pemerintah dengan dalil terlanggarnya hak-hak konstitusional warga negara. Dengan sendirinya ini menjadi tawaran baru bagi Mahkamah Konstitusi untuk dapat memberikan perlindungan terhadap hak-hak asasi manusia dan hak konstitusional warga negara dengan menggunakan mekanisme Citizen Lawsuit.

\footnotetext{
15 Ibid, h. 46
} 


\section{Kesimpulan}

Berdasarkan pembahasan di atas dapat disimpulkan bahwa gugatan warga negara (citizen lawsuit) merupakan Mekanisme Pemenuhan Hak Asasi Manusia dan Hak Konstitusional Warga Negara dan dimungkinkan Mahkamah Konstitusi Republik dapat memeriksa, mengadili dan memutus perkara gugatan warga negara (citizen lawsuit) dengan menggunakan dasar Undangundang Kekuasaan Kehakiman. Akan tetapi sudah seyogyanya negara melakukan revisi Undangundang Mahkamah Konstitusi dengan menambahkan kewenangan Mahkamah Konsitusi. Dan upaya lebih lanjutnya adalah perlu dilakukan amandeman Kelima UUD 1945.

\section{Daftar Bacaan}

Fadjar, A. Mukthie, Tipe Negara Hukum, Malang: Bayumedia dan In-Trans, 2003.

Gumayra, Dhabi K., Panduan Bantuan Hukum di Indonesia, Jakarta: Aussaid, YLBHI, PSHK dan IALDF, 2006.

Hermawanto, Panduan Bantuan Hukum di Indonesia, Jakarta: Aussaid, YLBHI, PSHK dan IALDF, 2008.

http://kanadianto.wordpress.com/2008/01/23/konsep-citizen-lawsuit-di-indonesia/. Diakses pada tanggal 6 Februari 2013.

MD., Moh. Mahfud, et.al., 2010, Constitutional Question : Alternatif Baru Pencarian Keadilan Konstitusional, Malang: UB Press. 